\title{
Numerical Modelling of Geothermal Reservoir in Gunung Talang, West Sumatera, Indonesia
}

\author{
Lia Putriyana ${ }^{1 *}$, Hari Soekarno ${ }^{1}$ \\ ${ }^{1}$ Research and Development Center for Electricity, New \& Renewable Energy, and Energy \\ Conservation Technology, Ministry of Energy and Mineral Resources, Republic of Indonesia. \\ Jl. Pendidikan No. 1, Pengasinan, Gunung Sindur, Bogor 16340 Indonesia
}

\begin{abstract}
Gunung Talang geothermal field is a part of Gunung Talang - Bukit Kili geothermal working area, which is located in Solok Regency, West Sumatera, Indonesia, about $54 \mathrm{~km}$ to the northeast of Padang city. A numerical model consisting of 1,680 grid blocks, covering an area of $17 \mathrm{~km}^{2}$ was developed for reservoir simulation. Two development strategies scenarios were constructed by considering various aspects such as reservoir behaviour, power plant's lifetime, environmental effects, resources, and prospect area. The power plant's power generation capacity and production lifetime of the scenarios are respectively $41,83 \mathrm{MW}$ with 106 years production lifetime from the first scenario and 79,53 MW with 54 years production lifetime from the second scenario. Nowadays, the Gunung Talang - Bukit Kili geothermal working area is being auctioned with a potential power generation of $65 \mathrm{MW}$.
\end{abstract}

Keywords: numerical model, geothermal reservoir.

Naskah masuk : 10 Mei 2019

Naskah direvisi : 24 Juni 2019

Naskah diterima : 30 Juni 2020

*Corresponding author.

Email: lia.putriyana@gmail.com

\begin{abstract}
ABSTRAK - Pemodelan numerik reservoir panasbumi di Gunung Talang, Sumatera Barat, Indonesia. Lapangan panas bumi Gunung Talang merupakan bagian dari Wilayah Kerja Panasbumi Gunung Talang - Bukit Kili yang terletak di Kabupaten Solok, Sumatera Barat, Indonesia, sekitar $54 \mathrm{~km}$ arah timurlaut Kota Padang. Model numerik yang terdiri dari 1.680 blok grid untuk area seluas $17 \mathrm{~km}^{2}$ dibuat untuk mensimulasikan reservoir. Dua skenario strategi pengembangan dibangun dengan mempertimbangkan beberapa aspek seperti perilaku reservoir, umur pembangkit, pengaruh terhadap lingkungan, sumber daya, dan area prospek. Kapasitas pembangkitan daya pembangkit listrik hasil skenario pertama adalah 41,83 MW dengan umur produksi 106 tahun, sedangkan skenario kedua menunjukkan kapasitas 79,53 MW dengan umur produksi 54 tahun. Saat ini, WKP Gunung Talang - Bukit Kili sedang dalam proses lelang dengan potensi pembangkitan listrik sebesar $65 \mathrm{MW}$.
\end{abstract}

Kata kunci: model numerik, reservoir panasbumi.

\section{INTRODUCTION}

Geothermal resources estimation method plays an important role for the quantification of geothermal energy that can be produced under current technology and economic situation. The methods used for geothermal resources and reserves estimation are vary at different stages of geothermal development considering the information that may available. Previously, various methods have been used for assessing the extractable energy, including: (1) estimation of natural heat flow that represents the long-term sustainability of available energy; (2) analogies based on other fields that have been produced for 
a long period; (3) summing outputs from existing wells; (4) volumetric assessment of heat in place and the portion that can be extracted; (5) lumped parameter models; (6) well decline analysis; and (7) numerical simulation reservoir models (Lawless, 2000). Geothermal resources evaluation is aimed to confirm the resources that can be utilized and to design the management to ensure production sustainability.

Volumetric reserves estimation and numerical modelling are two most common methods applied in geothermal resources assessment. In the early stage, the volumetric method is considered as the most suitable approach to accelerate area development (Sarmiento and Bjornsson, 2007). In addition, during the initial stage when green field has inadequate information, the volumetric (stored heat) method is most useful for resource estimation. However, as the oldest, this basic method has significant weaknesess. This method calculates several parameters including reservoir volume, rock and fluid properties, temperature, and recovery factor, which contains several factors that may subject to subjective assessment. The most debated parameter in this method is the recovery factor that describes how much energy can be recovered from a reservoir. Recovery factor is related to reservoir porosity and permeability, thus different reservoir system might give different value of recovery factor. For this reason, the stored heat method often leads to overestimation of the field capacity, sometimes in significant multiplication (Grant, 2000).

In the early stages of geothermal development, when available data is limited, a simply methods are used in assessing the reservoirs. But as more information is gathered on reservoir parameters and more experiences are gained in producing energy from the reservoir, a sophisticated numerical computer models are used to simulate the geothermal reservoir in its natural state and their response to the utilization, eventually, will determine the generating potential of the reservoir. The results of this study then serve as a basis for the drilling works of shallow and deep exploration wells to confirm the existence of a viable resource. The geothermal resources assessment must be updated with additional data obtained from several wells after they finished drilled. The objectives of this reservoir simulation include:

- Interpreting the exploration survey result,
- Estimating of power generating potential and expected lifetime,

- Determining appropriate locations for production and injection well,

- Assuring the appraisal of estimated capacity.

In this study, numerical models was generated using geoscience data from an integrated survey of geology, geochemistry, and geophysics. The data were considered adequate for numerical modelling in the early stage of geothermal development. Subsequently, the numerical model will be updated continuosly using the available production data after the exploitation of geothermal resources begin. This paper aimed to construct numerical models of Gunung Talang geothermal field and to estimate the electricity that can be generated from this prospect area.

\section{GEOLOGICAL BACKGROUND}

Gunung Talang geothermal field is typical of a stratovolcanoes (volcanic) geothermal system, located in the northeast of Talang Volcanoes (mainly andesite), and is situated in the middle of Great Sumatra Fault zone (Rohaendi and Agustine, 2016). Previous study (Santoso et al., 1995) reveals that the permeable zone in this region is controlled by faults trending northwestsoutheast, with more than $80^{\circ}$ dip. The presence of geothermal trap in the Gunung Talang geothermal field and the occurrence of possible heat source is indicated by a shallow intrusion body. Structurally, this prospective area is located in a graben (Santoso et al., 1995). The area is covered by Pre-Tertiary-Quartenary rocks that composed of metamorphic rocks (Trts: phyllite), old volcanic rocks (QTau: andesite, tuff breccia), lava (QLv: andesite, tuff breccia, pyroclastic) and surface deposit (QLh) (Idral, 2011). The metamorphic and volcanic rocks are mostly weathered, the volcanic rocks are also altered in some places that characterized by sericite and chlorite alteration mineral assemblage (Idral, 2011). Columnar and sheet joints that occurred on volcanic rocks created additional porosity and permeability, therefore, it becomes a good medium for the transfer of surface water down into the geothermal system in this area (Idral, 2011). Faults and rings (result of volcanic eruption) are common in this area. The faults are normal fault trending NW-SE, $\mathrm{N}-\mathrm{S}$ and NE-SW, among the faults, Batu 
Barjanjang Fault is most important as it controls the geothermal manifestation in Gunung Talang to the surface (Idral, 2011). The geological map of Gunung Talang - Bukit Kili is shown in Figure 1.

Thermal surface manifestations in the research area are dominated by hot springs, solfatara, fumarole, and altered rocks, in addition are phreatic eruptions, hydrothermal alteration and sinter carbonate. Geochemical studies show that the fluid in Gunung Talang geothermal manifestation is categorized as immature water (Munandar et al., 2003). The geothermal hot

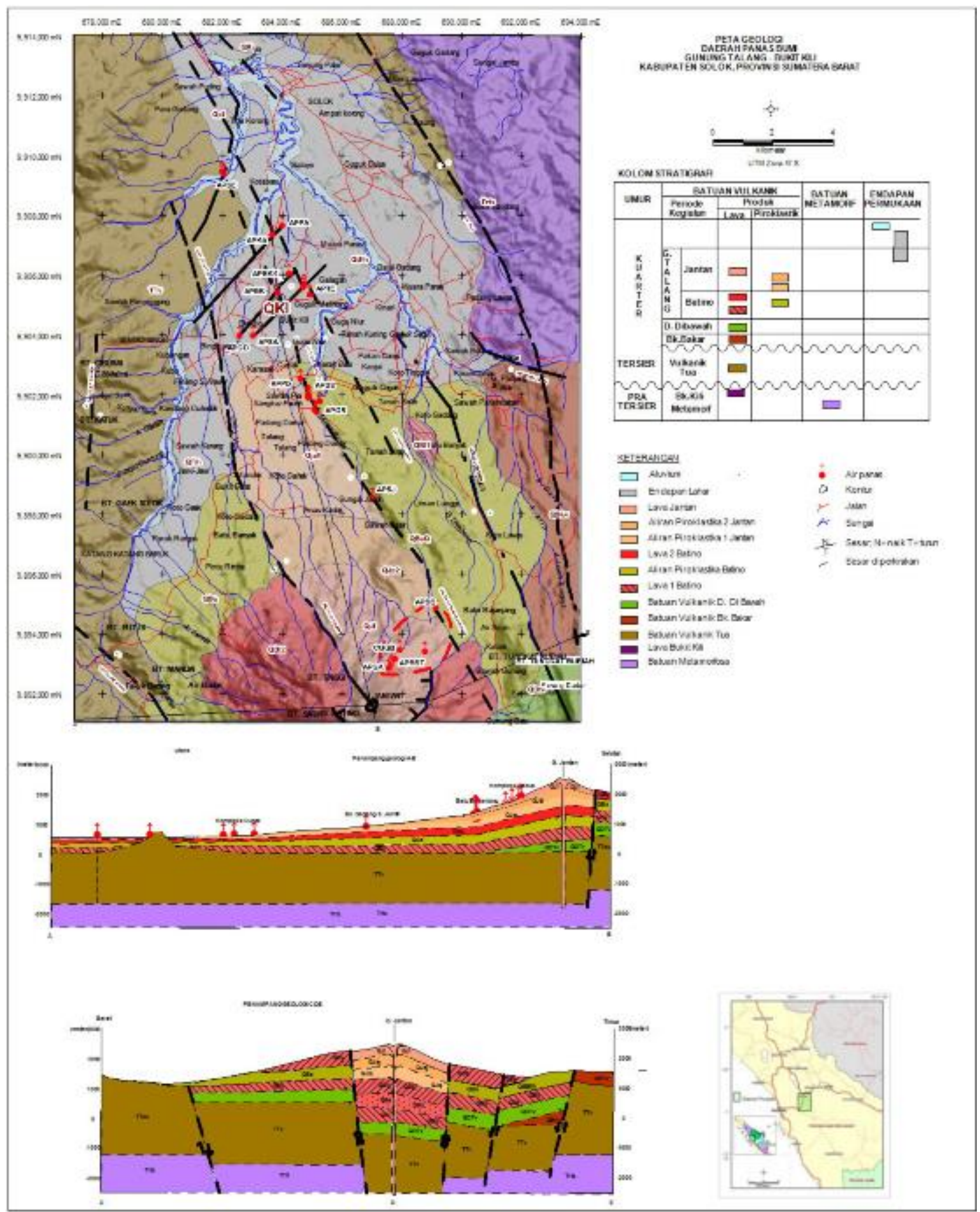

Figure 1. Geological map of Gunung Talang - Bukit Kili.

(Source: Pusat Sumber Daya Geologi, 2013) 
springs around Gunung Talang, which are categorized as immature water, indicate that the geothermal reservoir fluids have been diluted with other elements (Utami and Putra, 2018). These reservoir fluids derived from the new hydrothermal system that influenced by Gunung Talang magma. The boiling geothermal reservoir fluid is located below the subsurface at $150 \mathrm{~m}$ depth approximately (Utami and Putra, 2018).

Geophysical surveys have been conducted to identify anomaly zone and to determine the geothermal prospect area of Gunung Talang. Gravity method survey was conducted to delineate sub surface structures that control the geothermal system. Lineament of gravity anomaly (Bouguer, regional and residual anomalous) trending NWSE are coincident with the primary regional fault structure in Sumatera (Sumatera Fault). Gunung Talang fault system that displaced in lateral motion is considered to be a part of Sumatera Fault (Idral, 2011). Bouguer anomaly, in some places, show wrench faults patterns that indicate a fractured zone. This zone is identical to secondary permeability that creates reservoir zone (Idral, 2011). Magnetotelluric (MT) survey was conducted to provide a comprehensive insight into Gunung Talang geothermal system. The MT data shows the distribution of low resistivity anomaly of $<20 \mathrm{ohm}-\mathrm{m}$, started at 500 meters depth, that was interpreted as the caprock. Whereas, the resistivity value of $20-100 \mathrm{Ohm}-\mathrm{m}$ at $1,500 \mathrm{~m}$ depth was interpreted as the reservoir (Kholid and Marpaung, 2011).

One thermal gradient bore hole (TLG-1) has been drilled in Gunung Talang up to 803 meter depth. Thermal gradients were obtained from formation temperature measurement at $150,300,500,642$, 700 , and $800 \mathrm{~m}$ depths. The formation temperatures from these measurements were $29^{\circ} \mathrm{C}$ at $500 \mathrm{~m}$ depth, $19.6^{\circ} \mathrm{C}$ at $642 \mathrm{~m}$ depth, and $38.6^{\circ} \mathrm{C}$ at $800 \mathrm{~m}$ depth. The average gradient temperature obtained from this drill hole was $3,25^{\circ} \mathrm{C} / 100 \mathrm{~m}$ or proportional to the normal temperature gradient of earth $\left( \pm 3^{\circ} \mathrm{C}\right.$ per $\left.100 \mathrm{~m}\right)$ means that there are no

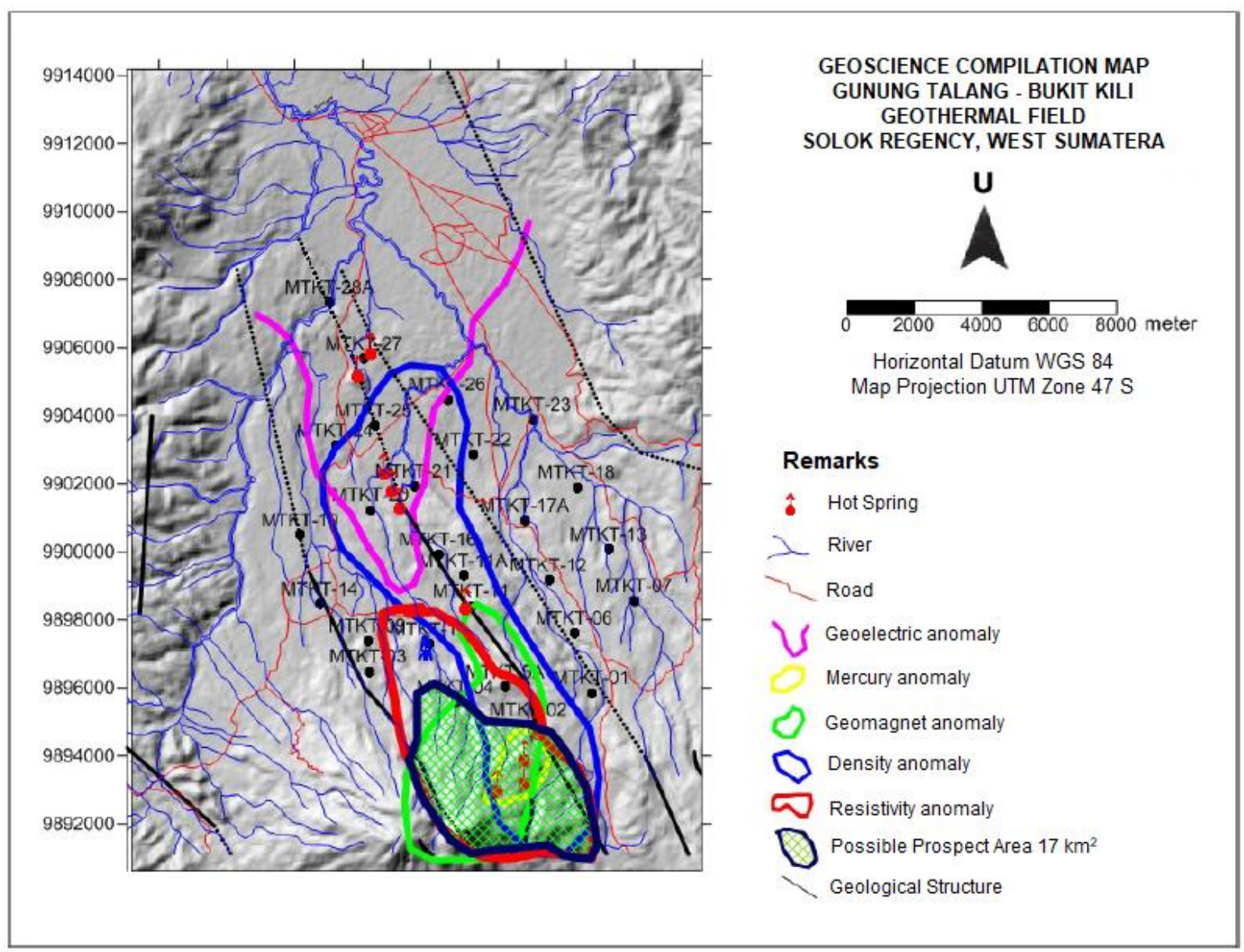

Figure 2. Compilation map of geothermal prospect of Gunung Talang - Bukit Kili (Source: Pusat Sumber Daya Geologi 2013). 
findings on indications of geothermal potential (Rezky et al., 2013).

Figure 2 is a geoscience compilation map of Gunung Talang geothermal field. It briefly describes the results of the geoscience surveys by overlying geophysical and geochemistry anomaly areas. The geophysical data derived from overlay of geoelectric, geomagnet, density and resistivity survey data, geochemistry survey data of mercury anomaly were also incorporated. The anomalous intersection area is predicted to be the location of the most potential prospect area of the Gunung Talang geothermal field which span for about 17 $\mathrm{km}^{2}$.

\section{Conceptual Model of Gunung Talang Geothermal Field}

Figure 3 briefly describes conceptual model of Gunung Talang geothermal field. The geothermal field is correlated with high terrain geothermal system, where the recharge area lies on the slope of Gunung Talang through rocks porosity as primary permeability; and fractures, lithology contact, joints and faults as secondary permeability (Pusat Sumber Daya Geologi, 2013). It is located at $560 \mathrm{~m}$ above sea level (masl). There are 13 hot springs locations as the outflows of Gunung Talang geothermal system, where the up flow is located around a complex fumarole named Air Panas (AP) Gabuo. The top reservoir of Gunung Talang geothermal system is presumed located at a depth of -1.500 to $-2.500 \mathrm{~m}$ in the subsurface. The heat source is located under the cone of Gunung Jantan that has active hydrothermal manifestations such as hot springs, fumaroles and solfataras. The cap is clay of argillic alteration from the altered volcanic rock of Gunung Talang, Jantan and Batino. Based on magnetotelluric survey interpretation, low resistivity zone is distributed at -500 to $-1500 \mathrm{~m}$ depth (Pusat Sumber Daya Geologi, 2013). Subsurface temperature was inferred from $\mathrm{SiO}_{2}$ geothermometer. The Gunung Talang geothermal fluid was identified neutral and has temperature of $160^{\circ} \mathrm{C}$ (Pusat Sumber Daya Geologi, 2013).

\section{METHODS}

Raw data used for numerical model sourced from the result of geoscience survey conducted by Pusat Sumber daya Geologi, Badan Geologi. Geochemistry data used in numerical model includes prediction of top reservoir temperature

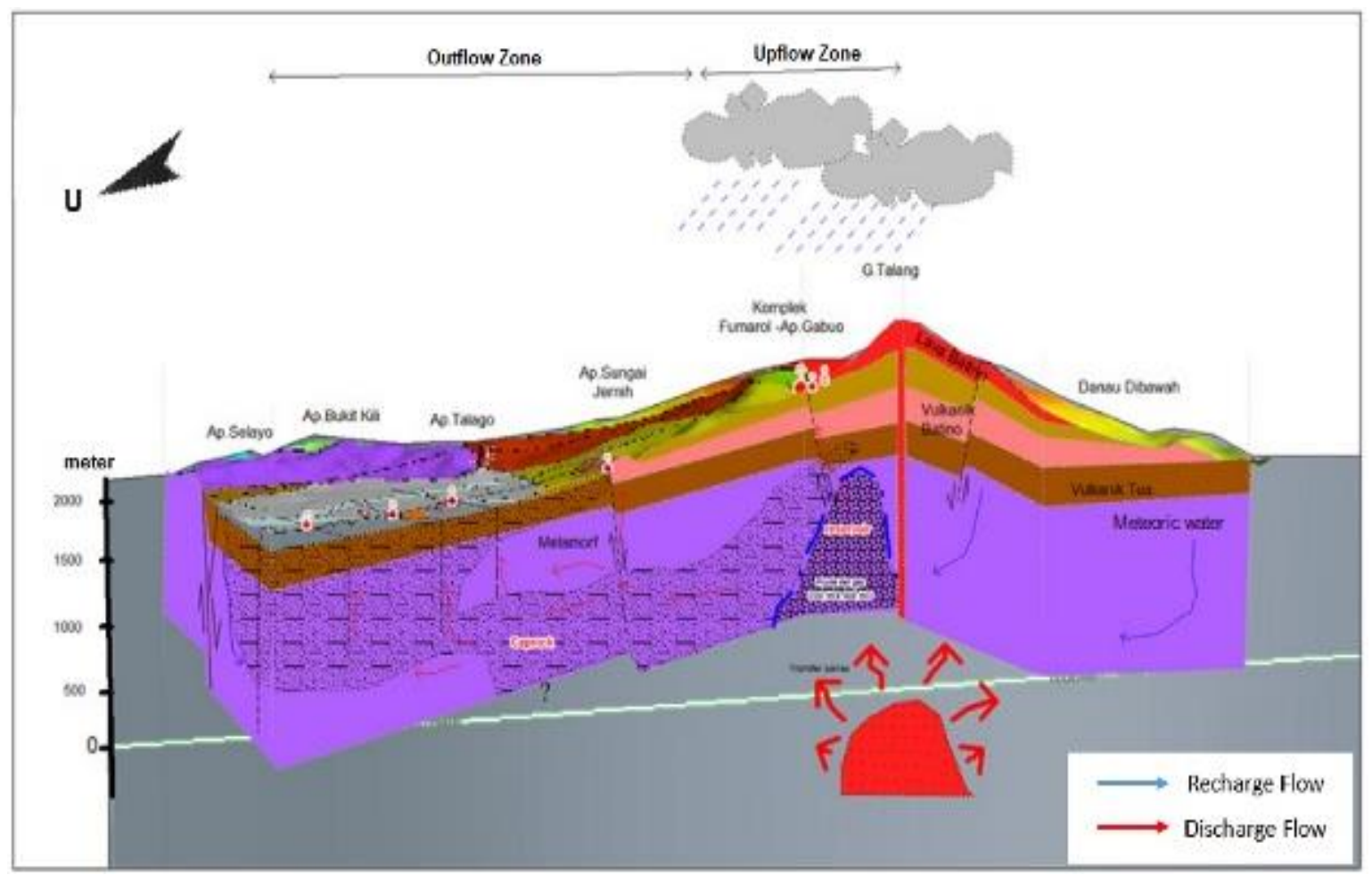

Figure 3. Model of Gunung Talang-Bukit Kili geothermal system, modified from tentative (Source : Pusat Sumber Daya Geologi, 2013). 
and surface manifestation (temperature and flow rate). Geological data is necessary to gain more understanding of regional geology, faults and types of rocks. While, geophysical data from magnetotelluric survey provides better understanding on the sub-surface conditions to determine reservoir location, heat source, and clay cap distribution.

Numerical model of Gunung Talang was generated for an area at the coordinate position of 678000, 9890000 and 694000, 9908000. Topographic contours were extracted from SRTM DEM $90 \mathrm{~m}$ resolution. The numerical model was generated using regular supporting meshes (grids) with simple geometries, finite differences, and low computational efforts. The meshing of Gunung Talang numerical model is shown in Table 1. In this numerical model, gridding is the first step for differential equation, while the size of grid affects the accuracy of the reserve calculation and fluid movement.

Table 1. Meshing of Gunung Talang numerical model.

\begin{tabular}{ccc}
\hline Direction & Cells & Cell Size \\
\hline $\mathrm{X}$ & 3 & 1600 \\
$\mathrm{X}$ & 10 & 800 \\
$\mathrm{X}$ & 2 & 1600 \\
$\mathrm{Y}$ & 12 & 900 \\
$\mathrm{Y}$ & 4 & 1800 \\
\hline
\end{tabular}

The model were divided into 9 layers in order to accommodate components of geothermal system such as caprock, reservoir and heat source. The provision of layer division was made by referring to the resistivity distribution data from the magnetotelluric survey result. As prementioned, magnetotelluric survey provides an understanding of sub-surface condition better than the other geophysic methods. Rocks properties were derived from trial and error in matching process. The rock properties of Gunung Talang numerical model are summarized in Table 2.

Material distribution used in Gunung Talang numerical model is based on interpretation of magnetotelluric survey data that has been conducted by Pusat Sumber Daya Geology. The vertical rocks distribution of reservoir layer of Gunung Talang numerical model is shown in Figure 4 and the lateral distribution is shown in
Figure 5. Pressure and temperature distribution of numerical model refers to the thermal gradient from TLG-1 bore hole with a depth of $800 \mathrm{~m}$. Numerical model of Gunung Talang geothermal field was developed based on the conceptual model. Three-dimensional numerical model consists of 1.680 computational blocks with single porosity was developed for reservoir simulation, using a commercial software package PetraSim ${ }^{\mathrm{TM}}$ (Thunderhead Engineering) as the interface of TOUGH2.

Detailed 3D numerical model was built based on the conceptual model to assess geothermal field in exploration stage. This model applied a linear temperature and hydrostatic pressure, and no-flow (heat and mass) boundary conditions. The numerical model was run in a steady state conditions, then calibrated using manifestation data and temperature profile of bore hole's thermal gradient from field measurement.

Table 2. Rock properties of Gunung Talang.

\begin{tabular}{|l|c|c|c|c|c|c|}
\hline \multirow{2}{*}{ Kind of Rock } & \multirow{2}{*}{ Colour } & \multirow{2}{*}{$\begin{array}{c}\text { Density, } \\
\mathbf{k g} / \mathbf{m}^{3}\end{array}$} & \multirow{2}{*}{\begin{tabular}{c} 
Porosity, \\
\cline { 4 - 6 }
\end{tabular}} & & \multicolumn{3}{|c|}{ Permeability, $\mathbf{m}^{2}$} \\
\cline { 5 - 7 } & & 1,2 & 99 & $1 \times 10^{-12}$ & $1 \times 10^{-12}$ & $1 \times 10^{-12}$ \\
\hline Atmosfer & & 2600 & 20 & $3 \times 10^{-15}$ & $3 \times 10^{-15}$ & $3 \times 10^{-15}$ \\
\hline Soil & & 2600 & 8 & $1 \times 10^{-17}$ & $1 \times 10^{-17}$ & $1 \times 10^{-17}$ \\
\hline Caprock & & 2600 & 10 & $2 \times 10^{-16}$ & $2 \times 10^{-16}$ & $2 \times 10^{-16}$ \\
\hline Rock A & & 2600 & 15 & $4 \times 10^{-15}$ & $4 \times 10^{-15}$ & $4 \times 10^{-15}$ \\
\hline Rock B & & 2600 & 5 & $3 \times 10^{-17}$ & $3 \times 10^{-17}$ & $3 \times 10^{-17}$ \\
\hline Rock C & & 2600 & 1 & $5 \times 10^{-17}$ & $5 \times 10^{-17}$ & $5 \times 10^{-17}$ \\
\hline Rock D & & 2600 & 5 & $5 \times 10^{-16}$ & $5 \times 10^{-16}$ & $5 \times 10^{-16}$ \\
\hline Rock E & & 2600 & 1 & $1 \times 10^{-19}$ & $1 \times 10^{-19}$ & $1 \times 10^{-19}$ \\
\hline Boundary & & 2600 & 6 & $1 \times 10^{-17}$ & $1 \times 10^{-17}$ & $1 \times 10^{-17}$ \\
\hline Base rock & & \multicolumn{4}{|l}{} \\
\hline
\end{tabular}

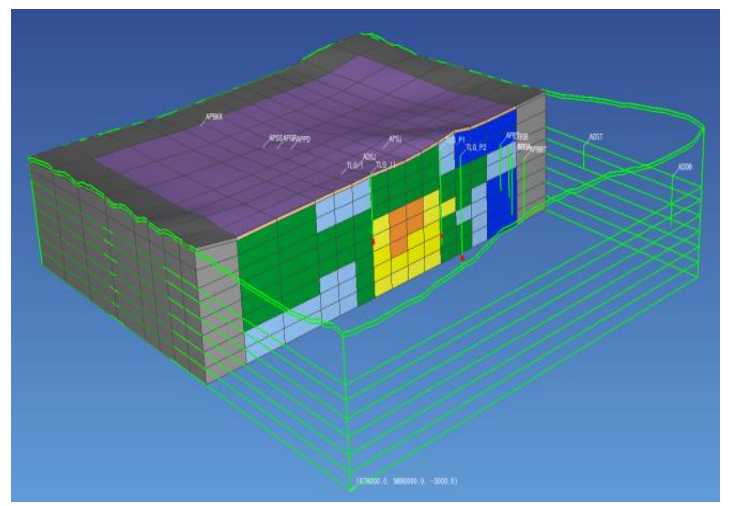

Figure 4. Rocks distribution of Gunung Talang numerical model. 

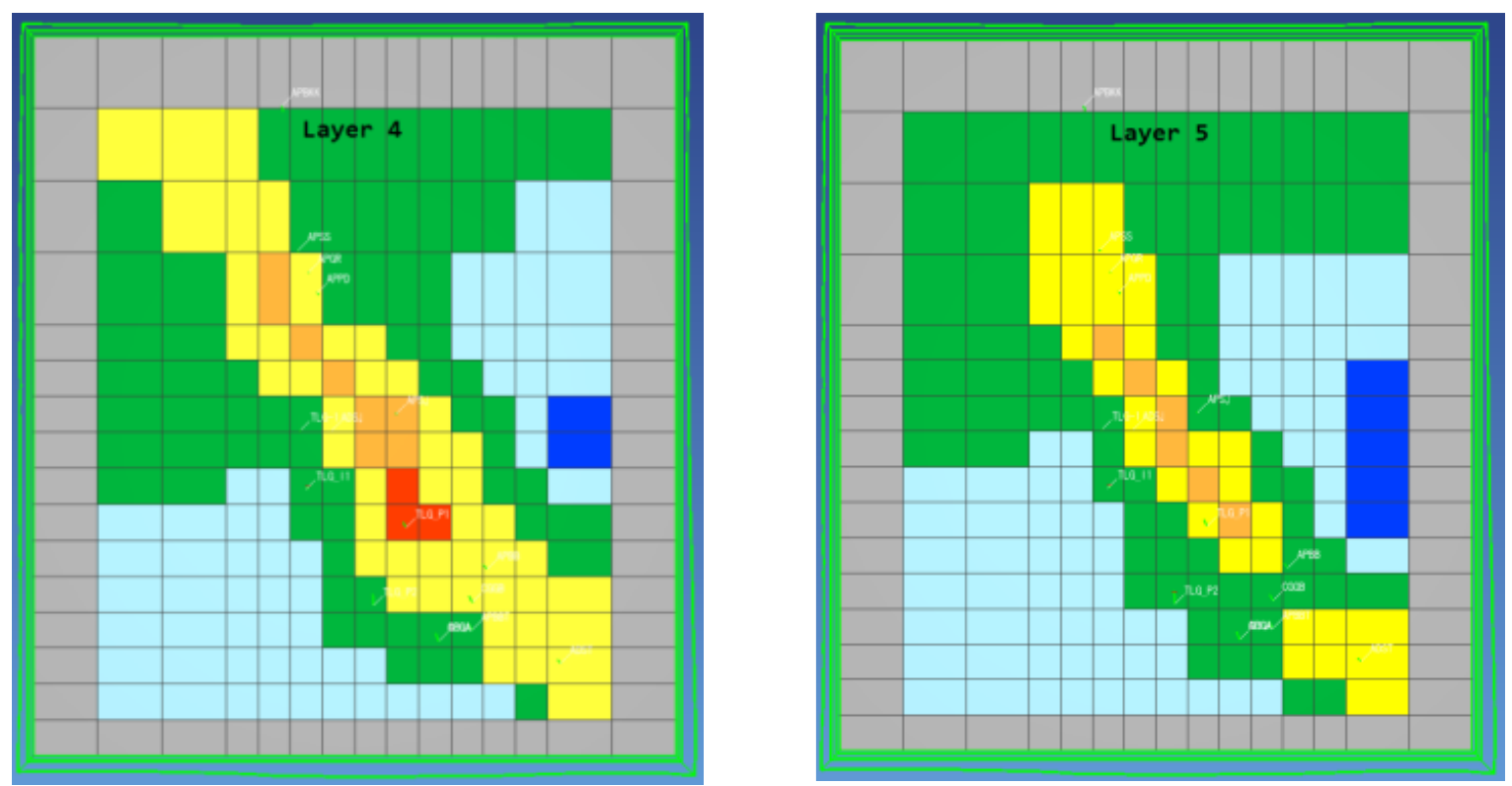

Figure 5. Rock distribution at reservoir layers.

Several information obtained from the integrated exploration surveys includes:

1. Reservoir area and its thickness obtained from geophysical anomaly data. Thermal gradient from the bore hole cannot be used due to its shallow depth.

2. Top reservoir temperature obtained from geothermometers data

3. Permeability and porosity have a large uncertainty, thus reference data is used to minimize these uncertainty factors.

Figure 6 shows lateral distribution of reservoir temperature at $-1000 \mathrm{~m}$ depth, and Figure 7 shows lateral distribution of reservoir temperature at $1500 \mathrm{~m}$ depth. The temperature distribution is aligned with the existences of manifestation area. The highest temperature distribution is located under the Gunung Talang cone as shown in Figure 8 , this picture shows the vertical distribution of reservoir temperature. As can be seen, the distribution of high temperature extends at a depth of -1500 meters .

\section{RESULTS}

\section{Model Validation}

Temperature validation is one parameters that describes a natural state condition that has been reached. Bore hole thermal gradient of Gunung Talang geothermal field shows a low gradient up to -100 meters depth. The graph for temperature validation is shown in Figure 9. The graph illustrates temperature validation of bore hole thermal gradient from the simulation result and field data.

Numerical modelling is a tool in developing strategies for field exploitation, production well location, and reinjection. The natural state of numerical model matched and validated using flow rate and enthalpy of the surface manifestations as shown in Table 3.

\section{DISCUSSIONS}

Reservoir porosity affects reservoir pressure behaviour during production stage. The model is assumed to have a constant rate of hot fluid. The percentage of fluid to re-inject is assumed to be $80 \%$, this assumption is made based on a study of hot-water systems that have the highest percentage $(80 \%)$ of produced mass that reinjected back into the reservoir (Diaz et al, 2016). Determination of reinjection well location is significant to ensure that the reservoir would not be affected by the reinjection fluid. Reinjection project for liquid dominated and two phase reservoirs should be designed to maximize thermal sweep of the reservoir. Pheriperal or dipole well configurations appear to be more suitable than reinjection well located in between production wells for this case (Sigurdsson et al, 1995). In the development scenario, two production wells were simulated for 


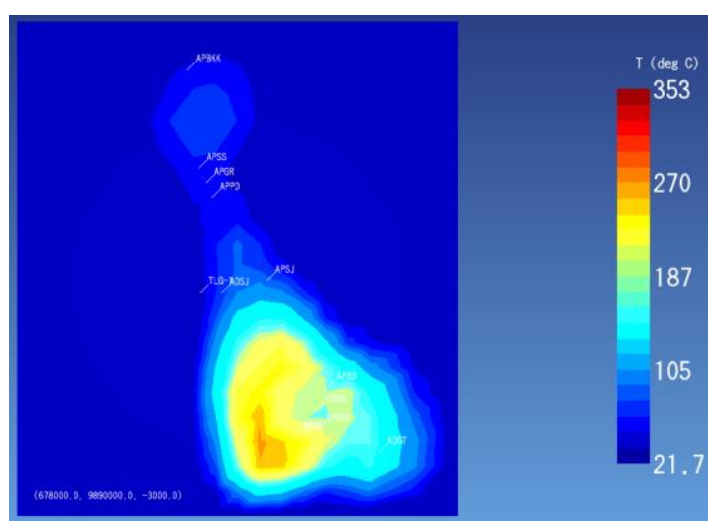

Figure 6. Lateral distribution of reservoir temperature at depth -1000 meter.

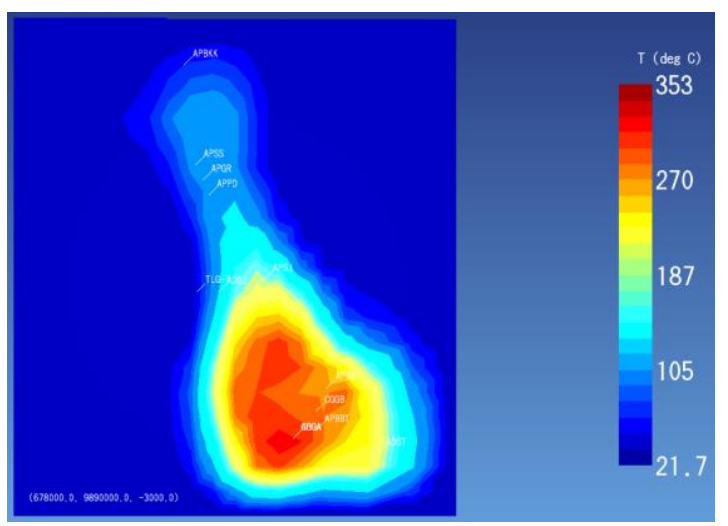

Figure 7. Lateral distribution of reservoir temperature at depth -1500 meter.

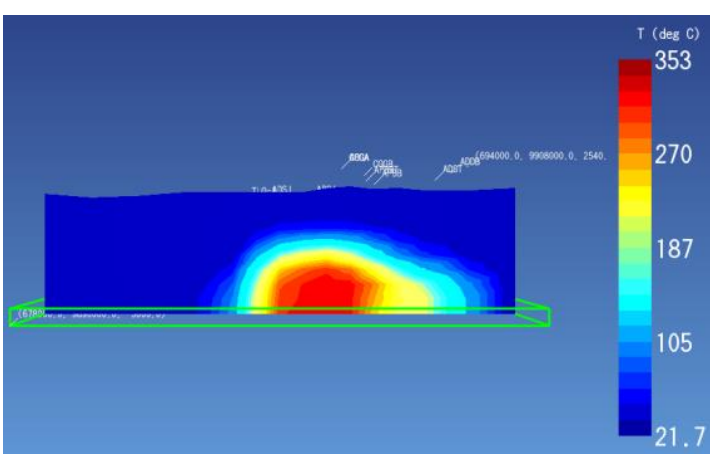

Figure 8. Vertical distribution of reservoir temperature.

productions. The location of production wells was selected in the prospect area and at a depth that thought to economically reachable by drilling.

The numerical model was built by considering the interpretation of exploration surveys data for developing numerical model of Gunung Talang.
During simulation process, the response of the numerical model will be observed to further analysis. The validated model can be utilized to make a forecast and development scenario, also to design a resource management plan.

\section{Development Scenario}

Reinjection temperature was obtained by a calculation on a design of single flash steam power plant with condensate temperature ranged from $40-50^{\circ} \mathrm{C}$. Selection of injection wells location was made with consideration of reservoir pressure support for a long term and prevented the significant effect of pressure drop in the reservoir. While selection of production well location was made by considering various aspects such as prospect area, height and depth of upper reservoir.

In this simulation, two scenarios were applied for appraisal of Gunung Talang geothermal field feasibility. These two scenarios were made for a comparation of which scenario is better between one production well and two production wells that might affect the capacity and lifetime. In first scenario, the rate of production well is $270 \mathrm{~kg} / \mathrm{s}$ and rate of injection well was set at $80 \%$ of production rate $(220 \mathrm{~kg} / \mathrm{s})$. The production well was set at a depth -1.000 below sea level and injection well at a depth -1.500 below sea level. The reservoir fluid enthalpy is $1.354 \mathrm{~kJ} / \mathrm{kg}$ with steam fraction of $13 \%$. In second scenario, the rate

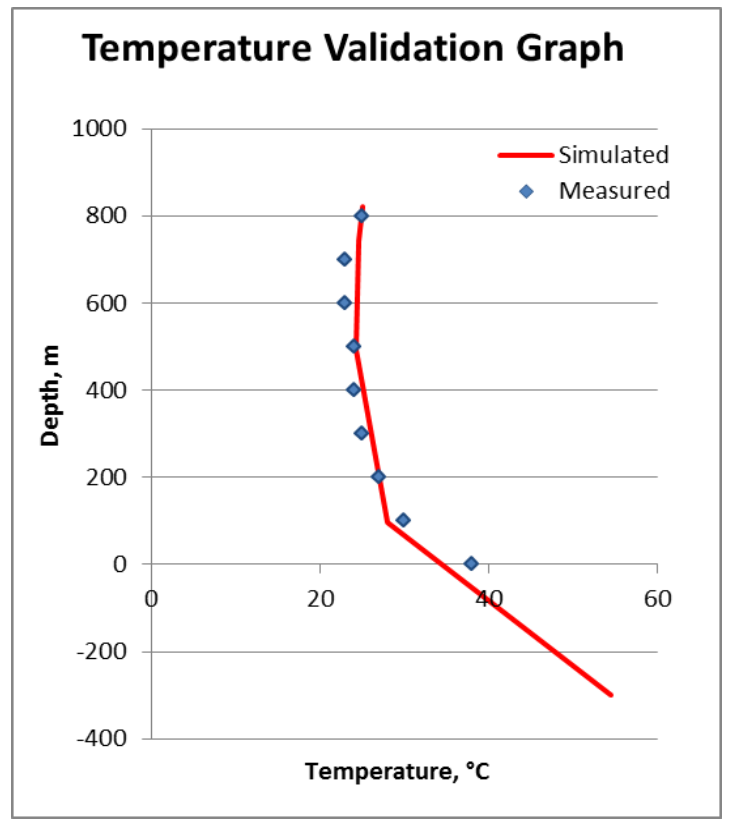

Figure 9. Temperature validation graph of thermal gradient from bore hole TLG-1. 
Table 3. Validation of measured manifestation data and simulation result.

\begin{tabular}{|c|c|c|c|c|c|c|c|}
\hline \multirow[b]{2}{*}{ No. } & \multirow[b]{2}{*}{ Name } & \multirow{2}{*}{$\begin{array}{c}\text { Temp } \\
\left({ }^{\circ} \mathrm{C}\right)\end{array}$} & \multicolumn{2}{|c|}{ Measurement } & \multicolumn{2}{|c|}{ Simulation } & \multirow[b]{2}{*}{ Remarks } \\
\hline & & & $\begin{array}{c}\text { Enthalpy } \\
\text { H, kg/kj }\end{array}$ & $\begin{array}{c}\text { Debit, } \\
\text { kg/s }\end{array}$ & $\begin{array}{c}\text { Enthalpy } \\
\text { H, kg/kj }\end{array}$ & $\begin{array}{c}\text { Debit, } \\
\text { kg/s }\end{array}$ & \\
\hline 1 & APGA & 95 & 397,92 & Not flowing & - & - & fumaroles, alteration \\
\hline 2 & APBBT & 47,8 & 200,05 & 20 & 130 & 20,61 & hot water, sinter carbonat \\
\hline 3 & APBB & 56,8 & 237,68 & 10 & 380 & 10,64 & hot water, sinter carbonat \\
\hline 4 & APSJ & 43,1 & 180,40 & 20 & 137 & 19,20 & hot water, sinter carbonat \\
\hline 5 & APPD & 55,5 & 232,25 & 2 & 178 & 2,77 & hot water, sinter carbonat \\
\hline 6 & APSS & 39,6 & 165,77 & 4 & 125 & 4,25 & hot water, sinter carbonat \\
\hline 7 & APGR & 53,7 & 224,72 & 1 & 111 & 0,89 & hot water, sinter carbonat \\
\hline 8 & APBKK & 50 & 209,25 & 2 & 189 & 0,15 & hot water, sinter carbonat \\
\hline 9 & ADDB & 23,1 & 96,82 & - & - & - & cold water, lake \\
\hline 10 & ADST & 19 & 79,68 & 10 & 110 & 10,56 & cold water \\
\hline 11 & ADSJ & 27 & 113,12 & 5 & 109 & 5,03 & cold water \\
\hline 12 & CGGA & 94,7 & 396,66 & & - & - & Fumaroles, Sublimation \\
\hline 13 & CGGB & 69 & 288,76 & & - & - & Fumaroles, Steaming Ground \\
\hline
\end{tabular}

of both production wells are made at $450 \mathrm{~kg} / \mathrm{s}$ and rate of injection well was set at $80 \%$ of production rate $(360 \mathrm{~kg} / \mathrm{s})$. The production well was set at a depth -1.000 below sea level and injection well at a depth -1.500 below sea level. The reservoir fluid enthalpy is $1.435 \mathrm{~kJ} / \mathrm{kg}$ with steam fraction of $21 \%$. Under assumptions of separator pressure at 12 bar, turbine inlet pressure at 9 bar, condensing type power plant, and condenser pressure at 0,1 bar; the steam mass that required to generate 1 MW electricity is $1,85 \mathrm{~kg} / \mathrm{s} / \mathrm{MW}$.

\section{CONCLUSIONS}

The numerical model of Gunung Talang geothermal field has been built and simulated. Two scenarios were made by considering various aspects of development such as reservoir behaviour, power plant lifetime, environmental effect, resources and prospect area. Power plant capacity that can be generated from scenario 1 is $41,83 \mathrm{MW}$ with 106 years production lifetime and scenario 2 is 79,53 MW with 54 years production lifetime. This numerical model is considered to be used in the early stages of geothermal development as basic data, but must be updated when production data is available.

\section{ACKNOWLEDGEMENTS}

We thank our colleagues from Pusat Sumber Daya Geologi (Geological Agency), who provided the integrated survey data of Gunung Talang geothermal field. Data for this research is fully supported by Pusat Sumber Daya Geologi.

\section{REFERENCES}

Diaz, Alexandre Rivera, Kaya, E., and Zarrouk, S. J., 2016. "Reinjection in Geothermal Fields - A Worldwide Review Update." Renewable and Sustainable Energy Reviews 105-162.

Grant, A. Malcolm, 2000. "Geothermal Resource Proving Criteria." World Geothermal Congress. Kyushu-Tohoku, Japan. 25812584.

Idral, Alanda, 2011. "Effects of Subsurface Topography and Hydrogeology on Gunung Talang Hot Water Systems, Sumatra, Indonesia: An Analysis Based 
on Gravity Data." Thirty-Sixth Workshop on Geothermal Reservoir Engineering. Stanford, California.

Kholid, Muhammad, and Marpaung, Harapan, 2011. "Survei Magnetotellurik Daerah Panasbumi Bukit Kili - Gunung Talang, Kabupaten Solok, Sumatera Barat." Prosiding Hasil Kegiatan Pusat Sumber Daya Geologi . Bandung, Indonesia: Geological Agency of Indonesia.

Lawless, Jim, 2000. Geothermal Lexicon for Resources and Reserves Definition and Reporting. Adelaide, Australia: Australian Geothermal Reporting Code Committee.

Munandar, A., Suhanto, E., Kusnadi, D., Idral, A., and Solaviah, M., 2003. "Penyelidikan Terpadu Daerah Panasbumi Gunung Talang Kabupaten Solok - Sumatera Barat." Kolokium Hasil Kegiatan Inventarisasi Sumber Daya Mineral. Bandung, Indonesia: Geological Agency of Indonesia.

Pusat Sumber Daya Geologi, 2013. "Daerah Panasbumi Gunung Talang - Bukit Kili, Kabupaten Solok, Provinsi Sumatera Barat." Usulan Wilayah Kerja Pertambangan (WKP). Bandung, Indonesia: Geological Agency of Indonesia.

Rezky, Y., Munandar, A., and Djukardi, D., 2013. Prosiding Hasil Kegiatan Lapangan Pusat Sumber Daya Geologi.
Bandung, Indonesia: Geological Agency of Indonesia.

Rohaendi, N., and Agustine, F., 2016.

"Geological and Mineralogical Studies on Long-Term Development of Geothermal Area: Case Study of Fault Fracture Density Analysis of Remotely Sensed Lineaments of Gunung Talang Geothermal Fields." PIT IAGI Ke-45. Bandung, Indonesia.

Santoso, D., Suparka, M. E., Sudarman, S., and Suari, S., 1995. "The Geothermal Fields in Central Part of the Sumatra Fault Zone as Derived from Geophysical Data." World Geothermal Congress. Florence, Italy. 1363-1366.

Sarmiento, Z. F., and Bjornsson, G., 2007. Geothermal Resource Assessment Volumetric Reserves Estimation and Numerical Modelling. Reykjavik, Iceland: United Nations University Geothermal Training Programme and La Geo.

Sigurdsson, O., Arason, P., and Stefansson, V., 1995. "Reinjection Strategy for Geothermal System." World Geothermal Congress. Florence, Italy. 1967-1971.

Utami, Z. D., and Putra, A., 2018. "Penentuan Karakteristik Fluida dan Estimasi Temperatur Reservoir Panasbumi di Sekitar Gunung Talang." Jurnal Fisika Unand Vol. 7, No. 2, April: 130-137. 